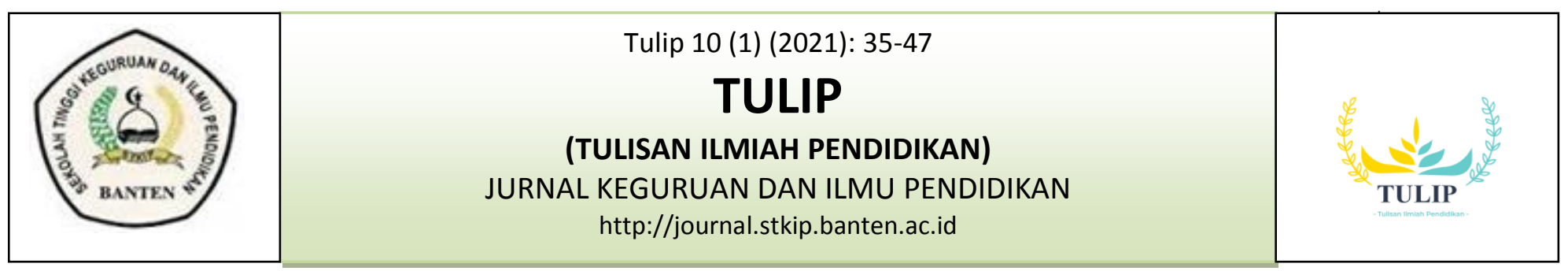

\title{
MODEL ACTIVE LEARNING TIPE ROLE REVERSAL QUESTION TERHADAP HASIL BELAJAR PPKN
}

\author{
Hasrul Muftahid ${ }^{1}$ dan Rohyati ${ }^{2}$ \\ ${ }^{1}$ Sekolah Tinggi Keguruan dan IImu Pendidikan Banten \\ ${ }^{2}$ Mahasiswa Pendidikan Pancasila dan Kewarganegaraan \\ hasrulmuftahid.com ${ }^{1}$ dan rohyati@gmail.com ${ }^{2}$ \\ Artikel Panggung Boneka Interaktif \\ Diterima: Januari, 2021 \\ Dipublikasikan: Maret, 2021
}

\begin{abstract}
The PPKn learning process in schools has not been fully involved directly, as happened in class XI. Learning activities are still dominated by teacher activities, namely by using the lecture method when explaining the subject matter. Therefore it is necessary to improve in PPKn learning, including the use of active learning model type role reversal question. The purpose of this study was to determine the improvement of PPKn learning outcomes using the Active Learning Model type role reversal question. This research is library research (Library Research). Researcher data collection uses scientific papers and journals, thesis and dissertation, thesis, and documentation. The results of classical data analysis showed an increase from the lowest $28 \%$ to the highest $38.46 \%$ with an average of $31.48 \%$, and before using the Active Learning Model Type Role Reversal Question from the lowest 53.85\% to the lowest the highest is $69 \%$ with an average of $40.95 \%$ and those who have used the Active Learning Model Type Role Reversal Question from the lowest $92.31 \%$ to the highest $97 \%$ with an average increase of $95.43 \%$.
\end{abstract}

Keywords: Active Learning, Type Role Reversal Question, PPKn Learning Outcomes 


\begin{abstract}
ABSTRAK
Proses pembelajaran PPKn di sekolah belum sepenuhnya terlibat secara langsung, seperti halnya yang terjadi pada kelas XI Kegiatan pembelajaran masih di dominasi oleh aktivitas guru yaitu dengan pengunaan metode ceramah saat menerangkan materi pelajaran. Oleh karena itu perlu adanya perbaikan dalam pembelajaran PPKn diantaranya penggunaan model pembelajaran active learning tipe role reversal question. Tujuan penelitian ini adalah untuk mengetahui Peningkatkan Hasil Belajar PPKn Menggunakan Model Active Learning tipe role reversal question. Peneltian ini adalah penelitian kepustakaan ( Library Research ), Pengumpulan data peneliti menggunakan paper dan journal ilmiah, tesis dan disertasi, skripsi, dan dokumentasi. Hasil analisis data secara klasikal menunjukan peningkatan dari yang terendah $28 \%$ sampai dengan yang tertinggi $38,46 \%$ dengan rata-rata $31,48 \%$, serta sebelum menggunakan model pembelajaran Active Learning Tipe Role Reversal Question dari yang terendah 53,85\% sampai dengan yang tertinggi $69 \%$ dengan rata-rata 40,95\% dan yang sudah menggunakan model pembelajaran Active Learning Tipe Role Reversal Question dari yang terendah 92,31\% sampai dengan yang tertinggi $97 \%$ dengan rata-rata peningkatan sebesar $95,43 \%$.
\end{abstract}

Kata Kunci : Active Learning, Tipe Role Reversal Question, Hasil Belajar PPKn.

\section{PENDAHULUAN}

Pendidikan diselenggarakan
dengan memberdayakan semua
komponen masyarakat melalui peran
serta dalam penyelenggaraan dan
pengendalian mutu layanan
pendidikan. Menurut Undang-Undang
Nomor 20 Tahun 2003 pendidikan
mempunyai andil yang penting dalam
menentukan proses pencapaian tujuan
pendidikan nasional yaitu
mengembangkan potensi peserta didik
agar menjadi manusia yang beriman
dan bertaqwa kepada Tuhan Yang
Maha Esa, berakhlak mulia, sehat,
berilmu, cakap, kreatif, mandiri dan
menjadi warga negara yang
demokratis serta bertanggung jawab.
Pendidikan dapat diartikan
sebagai suatu proses atau aktifitas
yang bertujuan agar tingkah laku

manusia yang mengalami pendidikan terjadi perubahan-perubahan. Belakangan pendidikan telah banyak malakukan pembaharuan atau inovasi pendidikan. Inovasi pendidkan yang terjadi dalam bidang pendidikan tersebut, antara lain adalah dalam menejemen pendidikan

Menurut Undang-Undang Nomor 20 Tahun 2003 PPKN merupakan mata pelajaran diwajibkan untuk jenjang pendidikan dasar, menengah dan mata kuliah

wajib untuk pendidikan tinggi. Pada jenjang sekolah dasar PPKN diajarkan kepada siswa yang berusia 7-12 tahun dimana menurut Piaget merupakan fase berkembangan "operasional konkret". Menurut Piagetdalam Desmitakarakteristik anak usia sekolah dasar masuk berada 
pada tahap operasional konkret, dimana aktivitas mental yang difokuskan pada obyek dan peristiwa yang

nyata ${ }^{1}$. Pendapat sama di kemukakan oleh Sri Esti Wuryani bahwa sebagian besar anak sekolah dasar yang berada dalam operasional konkret kurang mampu berfikir abstrak. Jika dilihat dari pemikiran dan karakteristik anak usia sekolah dasar, maka dalam pelaksanaan pembelajaran PPKN guru dapat merencanakan kegiatan yang mengandung unsur keterlibatan siswa secara langsung ${ }^{2}$.

Kenyataannya dalam proses pembelajaran PPKN di sekolah belum sepenuhnya terlibat secara langsung, seperti halnya yang terjadi pada kelas XI Kegiatan pembelajaran masih di dominasi oleh aktivitas guru yaitu dengan pengunaan metode ceramah saat menerangkan materi pelajaran. Berdasarkan observasi yang dilakukan pada saat kegiatan pembelajaran PPKN berlangsung, siswa yang tidak sepenuhnya memperhatikan penjelasan guru, dikarenakan bosan dengan aktivitas mendengarkan, sehingga pembelajaran PPKN dirasa kurang menyenangkan bagi siswa. Cara yang dapat ditempuh guru untuk meningkatkan kegiatan pembelajaran yaitu dengan mengunakan model pembelajaran yang bisa diterapkan di kelas. Model

${ }^{1}$ Desmita. (2009). Psikologi Perekembangan Peserta Didik: Panduan Bagi Orang Tua Dan Guru Dalam Memahami Psikologi Anak Usia $S D, S M P, S M A$. Bandung: PT. Remaja Rosdakarya. H 21

${ }^{2}$ Sri Esti Wuryani Djiwandono. (2002). Psikologi Pendidikan. Jakarta: Grasindo Garamedia Widiasarana Indonesia.h 44 pembelajaran merupakan pedoman dan segala sesuatu yang dibutuhkan dalam kegiatan pembelajaran baik berupa sumber, bahan atau alat yang akan digunakan. Hal ini sesuai dengan pendapat Joyce dan Weildalam Hamruni model pembelajaran adalah suatu perencanaan yang digunakan sebagai

\section{LANDASAN TEORI}

1. Pengertian Model Pembelajaran aktif (Actve Learning)

Pembelajaran aktif (active
learning) merupakan suatu pembelajaran yang menekankan siswa untuk aktif dalam belajar.Kegiatan pembelajaran lebih didominasi pada aktivitas siswa. Kegiatan pembelajaran tidak hanya menekankan pada aktivitas mental namun juga melibatkan aktifitas fisiksehingga suasana pembelajaran lebih nyaman dan menyenangkan ${ }^{3}$. Sedangkan menurut Ari Samadhi dalam Oktavia pembelajaran aktif (active learning) merupakan pembelajaran yang memungkinkan siswa turut aktif salam proses pembelajaran, baik dalam bentuk interaksi antar siswa maupun siswa dengan guru. ${ }^{4}$

Dari pendapat yang sudah dijelaskan dapat di ambil kesimpulan bahwa pembelajaran aktif(active learning) merupakan kegiatan belajar yang mengaktifkan siswa, dalam artian siswa terlibat langsung

\footnotetext{
${ }^{3}$ Hiszyam Zaini. (2008). Strategi

Pembelajaran Aktif. Yogyakarta: Insan Madani.h 20

${ }^{4}$ Jurnal.Oktavia.(2015). Pengaruh Active Learning Terhadap Peningkatan Aktivitas Belajar SiswA Pada Materi Pengelolaan Lingkungan.
} 
dalam pembelajaran. Pembelajaran aktif membutuhkan interaksi antara guru dengan siswa, serta melibatkan kemampuan siswa baik kognitif, afektif serta prikomotorik, yang diperoleh dari pengalaman belajar.

\section{Ciri Pembelajaran Aktif (Active Learning)}

Karakteristik pembelajaran aktif menurut Bonwell dalam Hamid yaitu dalam pembelajaran siswa tidak hanya pasif mendengakan penjelasan dari guru, namun kegiatan pembelajaran menekankan pada aktivitas belajar siswa. Sehingga siswa aktif dalam pembelajaran. Siswa dituntut untuk berfikir kritis, melakukan analisis dan melakukan evaluasi ${ }^{5}$. Dari hal tersebut diketahui bahwa proses pembelajaran menekankan pada pengembangan keterampilan menganalisis dan mengkritisi persoalan yang berkaitan dengan materi yang dipelajari untuk itu umpan balik dalam pembelajaran sering terjadi. Selain itu dalam kegatan pembelajaran

Dalam panduan pembelajaran Model Active Learning In School ciri pembelajaran aktif merupakan pembelajaran yang kegiatannya berpusat pada siswa. Pada pembelajaran aktif siswa di tuntut untuk berfikir kritis, sebab siswa sendiri yang mencari pengetahuannya melalui kegiatan langsung. Untuk itu lingkungan dapat digunakan sebagai media atau sumber belajar siswa. Dengan pembelajaran yang dikaitkan dengan kehidupan

${ }^{5}$ Moh. Sholeh Hamid. (2011). Metode

Edutaiment. Yogyakarta: Diva Press.h35 nyata dapat mendorong anak untuk berinteraksi dengan lingkungan.Kegiatan guru dalam proses pelaksanaan pembelajaran aktif yaitu memantau siswa dalam belajar. Guru memberikan arahan kepada siswa dalam menemukan pengetahuannya. Pembelajaran aktif menekankan pada aktifitas siswa daripada guru, namun guru tetap mengontrol jalannya kegiatan pembelajaran agar tidak terjadi perbedaan presepsi dalam belajar. Selain itu memberikan umpan balik juga dilakukan oleh guru kepada siswa.Pemberian umpan balik tersebut bertujuan untuk mengapreiasi kegiatan yang sudah, dilakukan siswa ${ }^{6}$.

Siswa belajar dengan baik dari pengalaman mereka.Pembelajaran aktif salah satunya ditandai dengan siswa belajar dari pengalamannya, selain itu siswa dapat memecahkan masalah yang diperoleh. Siswa belajar dengan caramelakukan, menggunakan panca indra mereka, menjelajahi lingkungan baik benda maupun tempat serta peristiwa-peristiwa yang ada di sekitarnya.

\section{Pengertian Model Active Learning Tipe Role Reversal Question}

Model pembelajaran aktif (active learning) bertujuan untuk membuat aktif dalam aktifitas belajar. Menurut Silberman, Mel (2017: 149) menyebutkan ada 101 pembelajaran aktif salah satunya role reversal question. Role reversal

\footnotetext{
${ }^{6}$ Hamzah B. Uno dan Nurdin Mohamad. (2012). Belajar dengan PendekatanPAILKEM:Pembelajaran Aktif, Inovatif, Lingkungan, Kreatif, Efektif, Menarik. Jakarta: PT.Bumi Aksara.h 37
} 
question merupakan kegiatan pembelajaran aktif yang menekankan pada aktivitas tanya jawab dengan pertukaran peran. Jika guru bertukar peran menjadi siswa maka guru mengajukan pertanyaan dan siswa mencoba menjawab pertanyaan. Begitupula sebaliknya jika siswa yang mengajukan pertanyaan maka guru yang menjawab.

Dari kegiatan tersebut diketahui bahwa terdapat kegiatan yang dilakukan siswa untuk aktif dalam pembelajaran. Terjadi interaksi antara guru dengan siswa, maupun siswa dengan siwa lain dalam kegiatan tanya jawab. Sehingga aktifitas pembelajaran tidak hanya guru memberikan ceramah mengenai materi pelajaran. Siswa juga latih untuk berani mengajukan pertanyaan serta memberikan pendapat, serta berfikir kritis dalam menjawab pertanyaan.

\section{a. Langkah-langkah Model Active Learning Tipe Role Reversal Question}

Langkah-langkah pembelajaran model active learning tipe role reversal question menurut Silberman antara lain ${ }^{7}$ :

1) Susunlah pertanyaan yang akan anda kemukakan tentang materi pelajaran seolah-olah anda seorang peserta didik.

2) Pada awal sesi pertanyaan, umumkan kepada peserta didik bahwa anda akan menjadi peserta didik dan peserta didik secara

\footnotetext{
${ }^{7}$ Silberman, Mel. (2017). Active Learning: 101 Strategi Pembelajaran Aktif.

Penerjemah: Sarjuli. Yogyakarta: Insan Madani.h 55
}

kolektif menjadi anda. Beralihlah lebih dahulu ke pertanyaan anda.

3) Berlakukah argumentatif, humoris, atau apa saja yang dapat membawa mereka pada perdebaran dan menyerang anda dengan jawabanjawaban.

4) Memutar peranan beberapa kali akan tetap membuat peserta didik anda pada pendapat mereka dan mendorongnya untuk melontarkan pertanyaan milik sendiri.

Langkah-langkah pembelajaran model active learning tipe role reversal question yang digunakan sesuai dengan pendapat diatas, namun ada beberapa hal yang disesuaikan dengan kemampuan dan kebutuhan siswa. Berikut ini adalah langkahlangkah pembelajaran modelactive learning tipe role reversal question yang telah dimodifikasi:

1) Siswa memperhatikan penjelasan guru mengenai kegiatan pembelajaran yang akan dilakukan

2) Siswa dibagi menjadi beberapa kelompok secara heterogen.

3) Setiap kelompok melakukan diskusi mengenai meteri pelajaran.

4) Siswa membuat pertanyaan mengenai materi pelajaran.

5) Siswa dan guru melakukan pemutaran peran untuk tanya jawab. Dengan ketentuan jika guru menjadi siswa maka guru memberikan pertanyaan yang sudah disiapkan (kartu pertanyaan), kemudian siswa menjawab pertanyaan tersebut, begitu pula sebaliknya. Jika siswa yang memberikan pertanyaan dan guru menjawab (kegiatan dilakukan berulang).

6) Guru memberikan umpan balik terhadap jawaban siswa. 


\section{Pengertian Belajar}

Menurut Slameto dalam Djamarah, belajar adalah suatu proses usaha yang dilakukan untuk memperoleh perubahan tingkah laku dari interaksi dengan lingkungannya yang diperoleh hasil pengalaman ${ }^{8}$. Pendapat serupa juga dikemukakan oleh Muhibinsyah bahwa belajar dapat dipahami sebagai tahapan perubahan pengalaman dan interaksi yang diperoleh dari lingkungan yang melibatkan proses kognitif. Perubahan tingkah laku dalam belajar diperlukan waktu dan proses yang bertahap.

Selain itu interaksi lingkungan juga berpengaruh, karena dalam belajar diperoleh pengalaman melalui interaksi lingkungan.Sedangkan menurut Syaiful Bahri Djamarah belajar merupakan kegiatan untuk memperoleh perubahan tingkah laku yang diperoleh dari suatu pengalaman dari interaksi lingkungan menyangkut aspek kognitif, afektif serta psikomotor. Perubahan tingkah laku tidak hanya terjadi karena memperoleh ilmu pengetahuan, melainkan juga pada saat memperoleh suatu pengalaman. Dengan melibatkan pengalaman langsung akanmempermudah terjadinya tingkah laku yang diharapkan setelah dilakukan kegiatan belajar. ${ }^{9}$

Dari beberapa pendapat di atas mengenai pengertian belajar dapat diketahui bahwa belajar merupakan kegiatan yang memiliki tujuan, menyangkut aspek kognitif, afektif dan psikomotorik yang menghasilkanotot kecil atau halus pada bagian tangan

${ }^{8}$ Saiful Bahri Djamarah.(2011).Psikologi

Belajar. Jakarta: Rineka Cipta.h 11

${ }^{9}$ Op.Cit h. 7 dengan menggunakan media sebagai alat bantu untuk melatih koordinasi mata dan tangan.perubahan perilaku setelah mengalami pengalaman. Melalui pengalaman menjadikan kegiatan pembelajaran lebih bermakna karena siswa terlibat langsung dalam belajar.

Menurut Sukmadinata dalam Suyono \& Hariyanto, prinsip umum belajar merupakan kegiatan yang berlangsung seumur hidup dan terjadi perkembangan pada individu yang melakukan kegiatan pembelajaran.Belajar dapat dilakukan dimana saja dan kapan saja, tidak mengenal ruang dan waktu.Kegiatan pembelajaran dapat dilakukan di lingkungan keluarga, di lingkungan sekolah, di lingkungan masyarakat dan ditempat lainya ${ }^{10}$.

Kegiatan pembelajaran mencangkup aspek kehidupan yakni mengembangkan kognitif, afektif, psikomotorik serta keterampilan hidup (life skill) untuk itu dibutuhkan bimbingan dan arahan dari orang lain. Arahan dan bimbingan dapat diperoleh dengan guru maupun tanpa guru misalnya teman sebaya atau orang yang berkompeten. Dengan adanya bimbingan dari orang yang berkompeten maka diharapkan akan mudah menerima transfer ilmupengetahuan sehingga tujuan dari kegiatan pembelajaran dapat tercapai.

Motivasi juga dibutuhkan dalam kegiatan pembelajaran, jika motivasi yang dimiliki rendah maka akan terjadi hambatan dalam belajar. Untuk itu diperlukan motivasi yang

\footnotetext{
${ }^{10}$ Suyono \& Hariyanto.(2011). Belajar dan Pembelajaran. Bandung: PT.Remaja Rosdakarya.h 23
} 
tinggi agar memiliki semangat dalam kegiatan pembelajaran serta tujuan pembelajaran dapat tercapai. Hambatan lain yang dapat mengganggu kegiatan pembelajaran selain motivasi yaitu lingkungan pembelajaran yang tidak mendukung.

Dari pengertian dan prinsip belajar yang sudah di jelaskan maka dapat dinyatakan bahwa belajar merupakan kegiatan yang berlangsung secara berkesinambungan dilakukan dimana saja dan berlangsung sampai akhir hayat. Belajar mengembangkan aspek kognitif, afektif, prikomotorik yang menghasilkan perubahan dalam tingkah laku, dan dalam kegiatan belajar membutuhkan bimbingan dari orang lain. Terdapat faktor-faktor yang mempengaruhi belajar baik dari dalam maupun faktor dari luar, untuk itu dapat dilakukan variasi dalam belajar agar kegiatan belajar sesuai dengan tujuan yang ingin dicapai.

\section{Ciri Karakteristik Belajar}

Menurut Brown dalam

M.Thobroni \& Arik Mustofa, karakteristik pembelajaran ialah sebagai berikut ${ }^{11}$.

a. Belajar adalah menguasai atau memperoleh.

b. Belajar adalah mengingat-ingat informasi atau keterampilan.

c. Proses mengingat-ingat melihat sistem penyimpanan, memori, dan organisasi kognitif.

\footnotetext{
${ }^{11}$ Muhammad Thobroni\& Arik Mustofa. (2013). Belajar\&

Pembelajaran:Pengembangan Wacana Dan Praktik Pembelajaran dalam Pembangunan Nasional . Yogyakarta:Ar-Ruzz Media
}

d. Belajar melibatkan perhatian aktif sadar dan bertindak menurut peristiwa-peristiwa di luar serta di dalam organisasi.

e. Belajar bersifat permanen, tetapi tunduk pada lupa.

f. Belajar melibatkan berbagai bentuk latihan, mungkin latihan yang ditopang dengan imbalan dan hukum.

g. Belajar adalah suatu perubahan dalam perilaku.

Berdasarkan pendapat tersebut diketahui bahwa belajar merupakan kegiatan yang bertujuan untuk menguasai atau memperoleh suatu pengetahuan.Dalam belajar dibutuhkan keterlibatan secara langsung.Keterlibatan tersebut dapat berupa mengingat-ingat suatu informasi atau dengan melakukan latihan. Dengan demikian dapat terjadi perubahan tingkah laku sesuai dengan yang diharapkan.

Sedangkan ciri-ciri belajar juga di kemukakan oleh Baharudin dan Esa Nur Wahyuni bahwa belajar merupakan perubahan perilaku yang bersifat relative permanent dan bersifat potensial.Dikatakan relative permanent karena saat belajar terjadi perubahan perilaku dalam kurun waktu tertentu. Perubahan perilaku yang terjadi hanya bersifat sementara tidak sampai pada akhir khayat. Kemudian dikatakan perubahan perilaku potensial dikarenakan perubahan perilaku yang terjadi tidak langsung dapat dilihat saat itu juga atau tidak terlihat langsung pada proses pembelajaran. Perubahan 
perilaku ini dapat dilihat saat pembelajaran selesai ${ }^{12}$.

Perubahan perilaku diperoleh dari kegiatan pengamatan maupun dari kegiatan yang berbentuk latihan. Dari suatu pengamatan seorang siswa dapat meniru perbuatan yang diamatinya. Sedangkan yang diperoleh dari bentuk latihan dapat dengan pengalaman langsung yang dilakukan siswa dalam kegiatan pembelajaran. Jika dalam pembelajaran kegiatan siswa mengamati serta dilatih secara langsung maka mudah untuk terjadi perubahan perilaku..

Dari

karakteristik

pembelajaran yang dikemukakan di atas dapat dinyatakan bahwa pembelajaran membutuhkan suatu proses yang menghasilkan perubahan tingkah laku. Dalam belajar membutuhkan memori dan organisasi kognitif untuk mengingat informasi yang diperoleh.

Selanjutnya, diterapkan pada sebuah latihan untuk merespon keaktifan siswa sehingga terjadi timbal balik dalam suatu pembelajaran dan terjadi perubahan tingkah laku yang dharapkan.

\section{Pengertian Hasil Belajar}

Tujuan akhir dilaksanakannya kegiatan pembelajaran yaitu untuk memperoleh hasil belajar. Menurut Oemar Hamalik hasil belajar diperoleh jika terjadi perubahan tingkah laku, dari tidak tahu menjadi tahu dan dari tidak mengerti menjadi mengerti. Perubahan tersebut dapat diartikan terjadinya peningkatan dan

\footnotetext{
${ }^{12}$ Baharudin \& Esa Nur Wahyuni. (2019).

Teori Belajar dan

Pembelajaran.Yogyakarta: Ar-Ruzz Media.
}

perkembangan lebih baik dari sebelumnya $^{13}$. Sedangkan menurut Agus Suprijono hasil belajar merupakan pola perbuatan, nilai-nilai, pengertian-pengertian, sikap-sikap, apresiasi dan keterampilan.Dengan demikian hasil belajar tidak hanya berdasarkan nilai atau skor yang diperoleh dalam kegiatan pembelajaran. $^{14}$

Hasil belajar menurut pemikiran Gagne dalam M.Thobroni \& Arik Mustofa, berupa informasi verbal, keterampilan intelektual, strategi kognitif, keterampilan motorik, dan sikap. Informasi verbal merupakan kemampuan dalam mengungkapkan pengetahuan baik dam bentuk bahasa, lisan maupuntertulis.Jika dikaitkan dalam pembelajaran untuk mengetahui pemahaman materi yang dikuasai siswa dapat dengan memberikan pertanyaan secara lisan maupun pertanyaan tertulis.Namun jika siswa dapat menjawab secara tertulis belum tentu dapat menjawab dengan lisan begitu pula sebaliknya untuk itu perlu diperhatikan perkembangan siswa dalam mengukur informasi verbal ${ }^{15}$.

\section{METODE PENELITIAN}

Studi literature dilakukan dengan cara mempelajari dan mengkaji buku-buku yang ada hubungannya dengan masalah yang diteliti untuk

\footnotetext{
${ }^{13}$ Oemar Hamalik. (2016). Proses Belajar Mengajar. Bandung: Bumi Aksara.h 17

${ }^{14}$ Agus Suprijono. (2019). Cooperative Learning: Teori dan Aplikasi PAIKEM. Yogyakarta : Pustaka Pelajar.h 44

${ }^{15}$ Muhammad Thobroni\& Arik Mustofa. (2013). Belajar\&

Pembelajaran:Pengembangan Wacana dan Praktik Pembelajaran dalam Pembangunan Nasional . Yogyakarta:Ar-Ruzz Media
} 
memperoleh bahan-bahan atau sumber-sumber tentang masalah yang akan diteliti. Teknik ini selain digunakan untuk melengkapi serta memperkuat landasan peneliti sebelum melakukan penelitiaan juga untuk melengkapi hasil penelitian yang peneliti lakukan $^{16}$.

Jenis penelitian ini adalah penelitan kepustakaan (library research), yaitu

Serangkaian penelitian yang berkenaan dengan metode pengumpulan data pustaka, atau penelitian yang obyek penelitiannya digali melalui beragam informasi kepustakaan (buku, ensiklopedi, jurnal ilmiah, koran, majalah, dandokumen) ${ }^{17}$. Penelitian kepustakaan atau kajian literatur (literature review, literature research) merupakan penelitian yang mengkaji atau meninjau secara kritis pengetahuan, gagasan, atau temuan yang terdapat didalam tubuh literature berorientasi akademik (academicoriented literature), serta merumuskan kontribusi teoritis dan metodologisnya untuk topic tertentu. Cooper dan Taylor dalam. Fokus penelitian kepustakaan adalah menemukan berbagai teori, hukum, dalil, prinsip, atau gagasan yang digunakan untuk menganalisis dan memecahkan pertanyaan penelitian yang dirumuskan. Metode pengumpulan data yang digunakan dalam penelitian ini meliputi data dari

\footnotetext{
${ }^{16}$ Diantama.Suarifqi, MetodePenelitianPendidikan.Bandung:Pustak aRahmat, 2018. Hal 34

${ }^{17}$ Nana Syaodih. 2010.

MetodePenelitianPendidikan. PT.

RemajaRosdakarya : Bandung. h.52
}

literature maupun refrensi yang ada mengenai kendala-kendala yang sering terjadi pada peningkatan hasil belajar PPKN menggunakan model Active Learning. Data yang digunakan sebagai berikut.

1. Paper dan Journal Ilmiah

Jurnal ilmiah adalah sebuah publikasi yang diterbitkan secara berkala oleh suatu organisasi profesi atau institusiak ademik yang memuat artikel-artikel yang merupakan produk pemikiran ilmiah secara empiris maupun dalam bidang ilmu tertentu.

2. Tesis dan disentasi

Tesis adalah pernyataan atau teori yang didukung oleh argument yang dikemukakan dalam karyatulis ilmiah resmi akhir mahasiswa.Tesis merupakan bukti kemampuan yang bersangkutan dalam penelitian dan pengembangan ilmu pada salah satu bidang keilmuan dalam ilmu pendidikan sesuai ilmu yang dipelajari.

3. Skripsi yang terdahuludan text book

4. Dokumentasi

Dokumentasi merupakan catatan peristiwa yang sudah berlalu, dapat berbentuk tulisan, gambar atau karya-karya dari seseorang. Dokumendigunakanuntukmenjaring data mengenai mengenai jumlah siswa dan hasil belajar siswa. Dokumenini yang akan digunakan dalam mengetahui pengaruh penerapan model pembelajaran Active Learning tipe Role Reversal Question terhadap hasil belajar dan keaktifan siswa dalam mengikuti pembelajaran. 


\section{HASIL DAN PEMBAHASAN}

Berdasarkan hasil analisis penelitian bahwa model pembelajaran Active Learning Tipe Role Reversal Question dapat meningkatkan hasil belajar siswa pada mata pelajaran PPKn. Hasil penelitian diatas dapat dilihat bahwa setiap penelitian yang telah dilakukan memperoleh hasil persentase yang menunjukan adanya peningkatan hasil belajar siswa, terlihat dalam kode data artikel A1 skor pretes menunjukan data dari $53,85 \%$ ketuntasan klasikal menjadi $92,31 \%$ sehingga peningkatannya $38,46 \%$, kode data A2 menunjukan dari $69 \%$ menjadi $97 \%$ dengan peningkatan mencapai $28 \%$, kode data A3 dari $69 \%$ menjadi $97 \%$ dengan peningkatan mencapai $28 \%$.

Adapun rata-rata hasil pretes sebelum menggunakam model pembelajaran Active Learning Tipe Role Reversal Question yaitu 40,95\% dan sesudah menggunakan model pembelajaran Active Learning Tipe Role Reversal Question meningkat menjadi $95,43 \%$ dengan rata-rata peningkatan 31,48\%. Dari hasil penelitian yang dilakukan penelitipeneliti sebelumnya bahwa model pembelajaran Active Learning Tipe Role Reversal Question dapat meningkatkan hasil belajar siswa pada mata pelajaran PPKn.

Belajar memerlukan kedekatan dengan materi yang hendak dipelajari, jauh sebelum bisa memahaminya. Belajar juga memerlukan kedekatan dengan berbagai macam hal, bukan sekedar pergaulan atau hafalan. Ketika kegiatan belajar bersifat aktif, peserta didik akan mengupayakan sesuatu. Dia menginginkan jawaban atas sebuah pertanyaan, membutuhkan informasi untuk memec ahkan masalah, atau mencari cara untuk mengerjakan $\operatorname{tugas}^{18}$. Penilaian hasil belajar oleh pendidik memiliki fungsi untuk memantau kemajuan belajar , memantau hasil belajar dan mendeteksi kebutuhan perbaikan hasil belajar peserta didik secara berkesinambungan $^{19}$.

Tes lebih cocok digunakan untuk mengetahui kemampuan siswa dalam aspek pengetahuan dan keterampilan (aspek kognitif dan aspek psikomotor), tidak cocok digunakan untuk mengukur sikap, karena sikap tidak dapat diinterpretasi kedalam benar atau salah, namun untuk mendapatkan deskripsi tentang profil sikap siswa. ${ }^{20}$

Kriteria ketuntasan minimal menjadi acuan bersama pendidik, siswa, dan orang tua siswa. Oleh karena itu, pihak-pihak yang berkepentingan terhadap penilaian di sekolah berhak untuk mengetahuinya. Satuan pendidikan perlu melakukan sosialisasi agar informasi dapat diakses dengan mudah oleh siswa dan orang tuanya.

$\begin{array}{lll}\text { Kriteria ketuntasan minimal } \\ \text { harus dicantumkan dalam } & \text { Laporan }\end{array}$

\footnotetext{
${ }^{18}$ Silberman, L. Melvin. (2013). Active Learning 101 Cara Belajar Siswa Aktif.

Bandung : Nuansa Cendekia. Hal 27.

19 Widoyoko, Putro E. (2018). Penilaian Hasil Pembelajaran disekolah. Yogyakarta : Pustaka Pelajar. Hal 18.

20 Widoyoko, Putro E. (2018). Penilaian Hasil Pembelajaran disekolah. Yogyakarta : Pustaka Pelajar. Hal 65.
} 
Hasil Belajar (LHB) sebagai acuan dalam menyikapi hasil belajar siswa. ${ }^{21}$

Dari data yang sudah peneliti analisis adanya perbedaan kenaikan persentase hasil belajar dalam artikel tersebut terkait penggunaan model pembelajaran Active Learning Tipe Role Reversal Question, peneliti menganalisis hal ini disebabkan karena adanya beberapa faktor terkait perbedaan tersebut yaitu faktor internal dan faktor eksternal. Faktor internal adalah faktor yang muncul dari dalam diri siswa seperti jasmaniah, psikologis dan kelelahan sedangkan faktor eksternal adalah faktor yang diakibatkan dari luar diri siswa seperti kondisi keluarga di rumah, keadaan sekolah, dan kondisi masyarakat sekitar rumah dan sekolah, sehingga akan berpengaruh terhadap konsentrasi dan kesiapan peserta didik untuk mengikuti kegiatan belajar dan juga mempengaruhi hasil belajar siswa dalam proses pembelajaran.

\section{SIMPULAN DAN SARAN}

\section{Simpulan}

Berdasarkan hasil temuan dan pembahasan dalam sumber data berupa artikel dalam jurnal menunjukan adanya peningkatan hasil belajar siswa. Hasil analisis data secara klasikal menunjukan peningkatan dari yang terendah $28 \%$ sampai dengan yang tertinggi $38,46 \%$ dengan rata-rata $31,48 \%$, serta sebelum menggunakan model pembelajaran Active Learning

\footnotetext{
${ }^{21}$ Widoyoko, Putro E. (2018). Penilaian Hasil Pembelajaran disekolah. Yogyakarta : Pustaka Pelajar. Hal 341.
}

Tipe Role Reversal Question dari yang terendah 53,85\% sampai dengan yang tertinggi $69 \%$ dengan rata-rata $40,95 \%$ dan yang sudah menggunakan model pembelajaran Active Learning Tipe Role Reversal Question dari yang terendah $92,31 \%$ sampai dengan yang tertinggi $97 \%$ dengan rata-rata peningkatan sebesar 95,43\%. Artinya terdapat peningkatan hasil belajar siswa dengan mengggunakan model pembelajaran Active Learning Tipe Role Reversal Question pada pembelajaran PPKn. Dari hasil jurnal penelitian bahwa model pembelajaran Active Learning Tipe Role Reversal Question pada pembelajaran PPKn dapat diterapkan disemua jenjang baik SD, SMP, maupun SMA. Karena model pembelajaran tersebut membuat peserta didik aktip dalam melakukan kegiatan, baik diskusi, tanya jawab, presentasi, dan membuat kesimpulan.

\section{Saran}

Penelitian yang dilakukan ini hendaknya harus dilakukan teliti dan detail sehingga dapat meminimalisir hasil data yang kurang sesuai, juga pemilihan sumber data juga harus lengkap tanpa ada batasnya agar data yang dihasilkan lebih banyak serta kualitas penelitian ini dikategorikan baik. Model pembelajaran Active Learning Tipe Role Reversal Question paling efektif jika pada saat proses pembelajaran adanya ketersediaan fasilitas atau sarana prasarana yang mendukung dalam proses pembelajaran, baik itu media ataupun yang lainnya agar tujuan dari proses pembelajaran dapat tercapai dengan baik. Terlebih dengan kondisi dan situasi saat ini yang diakibatkan oleh 
adanya pandemi COVID 19 yang tidak tahu kapan selesainya, membuat peneliti kesulitan mencari sumber data yang melibatkan banyak orang atau terjun kelapangan jadi terhambat, akan tetapi waktu penelitian terus berjalan. Untuk itu antisipasi dari peneliti menyarankan jika ingin melakukan penelitian tanpa harus mencari sumber data melibatkan banyak orang ataupun terjun langsung ke lapangan bisa menggunakan penelitian yang seperti ini.

\section{DAFTAR PUSTAKA}

Agus Karoni. (2011). Pembelajaran Active Learning Starts With a Question untuk meningkatkan keaktifan bertanya siswa dalam pembelajaran PKn kelas IV MIM Sraten, Sukoharjo Tahun Ajaran 2010/2011. Skripsi.UIN Sunan Kalijaga Yogyakarta.

A.Ubaedillah \& Abdul Rozak. (2013). Pendidikan Kewarganegaraan (CivicEducation): Pancasila, demokrasi, hak asasi manusia dan masyarakat madani. Jakarta: ICCE UIN Syarif Hidayatullah

Aripin, Zainal. (2011). Evaluasi Pembelajaran . Bandung : PT Remaja Rosdakarya. Hal. 303

Ari Samandhi. (2009). Pembelajaran Aktif (Active Learning). Jakarta: Teaching Improvement Worshop Enginering Education Develompment Project.
Darmadi, Hamid. (2012). Kompetensi Dasar Mengajar. Bandung : Alfabeta. Hal 115. . (2012). Kompetensi Dasar Mengajar . Bandung : Alfabeta. Hal 178.

Hamruni. (2011). Strategi Pembelajaran. Yogyakarta: Insan Madani.

Hamzah B. Uno dan Nurdin Mohamad. (2012). Belajar dengan Pendekatan PAILKEM:Pembelajaran Aktif, Inovatif, Lingkungan, Kreatif, Efektif, Menarik. Jakarta: PT.Bumi Aksara.

Jalaludin, (2017). Meningkatkan Hasil Belajar PKn Materi Kebebasan Berganisasi dengan Metode Role Reversal Question pada SiswaKelas V SDN Sisik Timur Tahun Pelajaran 2017/2018 http://ejournal.mandalanursa.or g/index.php/JIME/index. Diakses 12 September 2020.

Moh. Sholeh Hamid. (2011). Metode Edutaiment. Yogyakarta: Diva Press.

Permendiknas No.22 Tahun (2006) tentang Standar Isi untuk Satuan Pendidikan Dasar dan Menengah Dasar. Diakses dari http://bnspindonesia.org/id/?page_id=103 padatanggal 28 meii 2020 , jam 16.36 WIB

Redja Mudyahardjo. (2012). Pengantar Pendidikan. Jakarta: Rajawali Pers.

Pengantar Pendidikan. Jakarta: Rajawali Pers. 
R. Ibrahim dan Nana Syaodih Sukmadinata.(2010).

Perencanaan Pengajaran. Jakarta: Rineka Cipta.

Silberman, L. Melvin. (2013). Active Learning 101 Cara Belajar Siswa Aktif. Bandung : Nuansa Cendekia. Hal 27.

Tisna (2013). Aktivitas Guru. Diakses melalui http://tisnadj.blogspot.com/makalahaktivitas guru.

Widoyoko, Putro E. (2018). Penilaian Hasil Pembelajaran disekolah . Yogyakarta : Pustaka Pelajar. Hal 18.

(2018).

Penilaian Hasil Pembelajaran disekolah. Yogyakarta : Pustaka Pelajar. Hal 65.

(2018). Penilaian Hasil Pembelajaran disekolah . Yogyakarta : Pustaka Pelajar. Hal 341.

(2018).

Penilaian Hasil Pembelajaran disekolah . Yogyakarta : Pustaka Pelajar. Hal 24. 